\title{
Seaweed as potential plant growth stimulants for agriculture in Mexico
}

\section{Las algas como potenciales estimulantes del crecimiento vegetal para la agricultura en México}

\author{
Rosalba Mireya Hernández-Herrera', Fernando Santacruz-Ruvalcaba', Diego Ramón Briceño-Domínguez², Dania Andrea Di \\ Filippo-Herrera ${ }^{3}$ and Gustavo Hernández-Carmona ${ }^{3}$
}

¿Laboratorio de Biotecnología, Departamento de Botánica y Zoología, Centro Universitario de Ciencias Biológicas y Agropecuarias, Universidad de Guadalajara. Calle Ramón Padilla Sánchez 2100, Col. Nextipac, Zapopan, Jalisco, 45110. México ¿2aboratorio de Ciencias Básicas, Instituto Tecnológico Superior de Felipe Carrillo Puerto. Carretera a Vigia Chico Kilómetro 1.5, Centro. Felipe Carrillo Puerto, Quintana Roo,

${ }^{3}$ Laboratorio de Química de Algas Marinas. Departamento de Desarrollo de Tecnologías, Centro Interdisciplinario de Ciencias Marinas (CICIMAR), Instituto Politécnico Nacional. Av. Instituto Politécnico Nacional S/N Col. Playa Palo de Santa Rita, La Paz, Baja California Sur, 23096. México e-mail: gcarmona@ipn.mx

Recibido: 23 de marzo de 2017.

Aceptado: 20 de marzo de 2018.

Hernández-Herrera R. M., F. Santacruz-Ruvalcaba, D. R. Briceño-Domínguez, D. A. Di Filippo-Herrera and G. Hernández-Carmona. 2018. Seaweeds as Potential Plant Growth Stimulants for Agriculture in Mexico. Hidrobiológica 28 (1): 129-140. D0l: 10.24275/uam/izt/dcbs/hidro/2018v28n1/HernandezC

\begin{abstract}
Background. One of the promising directions in agriculture is the rational use of biologically active substances or plant growth stimulators obtained from local raw materials. In Mexico, seaweed can be considered a cheap, abundant, and accessible local resource along the Mexican coast. It represents great potential for eventual commercial exploitation as a source of plant growth promoters. Previous reports have emphasized the importance of seaweed extracts and their utilization with significant results to improve seed germination, seedling development, growth, and yield of plants, increasing crop productivity. The main effects should be in the first stages of plant ontogenesis, beginning with seed germination and seedling growth. The effects of seaweed liquid extracts in the early stages of plant growth are on root-system growth, providing a signal of the value and quality of the future crop. Therefore, the search for the most effective extracts that stimulate plant development is considered a priority. Goals. Show an overview of the application of seaweed extracts in Mexican agriculture. Results. Information is provided on the administration and regulation for the harvest of marine algae, and the research carried out in Mexico. The management and harvest regulations for the algae, including seaweed liquid extract composition, biological efficacy of promoting plant growth, as well as elicitors of disease defense caused by pathogens. Conclusions. Seaweeds from Mexico have enough potential for the isolation of biologically active compounds that could increase agriculture productivity. This research is essential for the future of Mexican agriculture, to develop effective strategies to use seaweed extracts.
\end{abstract}

Keywords: agriculture, biostimulants, extracts, seaweeds

\section{RESUMEN}

Antecedentes. Una de las áreas prometedoras en la agricultura es el uso racional de sustancias biológicamente activas como estimulantes del crecimiento de plantas, obtenidos de materias primas locales. En México, las algas marinas pueden ser consideradas como un recurso local económico a lo largo de su costa, que está disponible y en abundancia. Representa un gran potencial para su eventual explotación comercial como bioestimulante del crecimiento de las plantas. En estudios previos se ha enfatizado la importancia de los extractos de algas y su uso con resultados significativos para mejorar la germinación de las semillas, el crecimiento y el rendimiento de las plantas, acrecentando la productividad de los cultivos. Por lo tanto, la búsqueda de extractos efectivos que estimulan el desarrollo de las plantas se considera prioritaria. Objetivos. Mostrar una visión general de la aplicación de extractos de algas marinas en la agricultura mexicana. Resultados. Se muestra la diversidad de la flora algal con potencial como biofertilizante y se presenta una reseña histórica del manejo y regulaciones de cosecha en México. Se describe la industria mexicana de los extractos de las algas con aplicación en la agricultura, incluyendo la composición química de los extractos algales, su eficacia biológica en el crecimiento de las plantas, así como inductores de defensa contra enfermedades causadas por patógenos. Además, se indican las investigaciones actuales del uso de extractos de algas en algunos cultivos. Conclusiones. Las algas marinas de México tienen un alto potencial para el aislamiento de compuestos biológicamente activos que podrían aumentar la productividad agrícola. La información presentada es esencial para que, en un futuro, la agricultura mexicana desarrolle estrategias efectivas del uso de extractos de algas marinas.

Palabras clave: agricultura, algas marinas, bioestimulantes, extractos 


\section{INTRODUCTION}

Many species of seaweeds, mainly brown algae, are widely used in agriculture as plant biostimulants, plant growth regulators, biofertilizers, or metabolic enhancers (Hong et al., 2007). Seaweed extracts can act by increasing plant vigor and vitality due to the presence of several bioactive substances that are important for plants (Khan et al., 2009; Gupta \& Abu-Ghannam, 2011). Also, they can improve nutrient uptake from soil (Turan \& Köse, 2004). There are many advantages of using seaweed extracts as stimulants of plant growth, including higher germination rates, root-system development, increased leaf area, fruit quality, and plant vigor (Hong et al., 2007; Rayorath et al., 2008; Khan et al., 2009; Craigie, 2011; Vinoth et al., 2012a, b; Mattner et al.. 2013; Vinoth et al., 2014). Besides this, plants treated with seaweed extracts have a higher content of biochemical constituents such as chlorophyll, carotenoids, protein, and amylases (Zhang \& Schmidt, 2000; Thirumaran et al., 2009; Gireesh et al., 2011), and treated plants acquire more resistance against pathogens (Jayaraj et al., 2008; Vera et al., 2011a, b; González et al., 2013a, b; Satish et al., 2015a, b; Ali et al., 2016).

As these beneficial effects are obtained with small doses of seaweed extracts, it is suggested that the active compounds could be growth hormones that occur naturally in seaweeds, such as auxins, cytokinins, gibberellins, or other low molecular weight components (polyamines and brassinosteroids) that are also effective at low concentrations (Hernández-Herrera et al., 2016). In addition, higher components identified in algal extracts such as polyphenols (phloroglucinol and its derivate eckol) promote growth activity, as well as polysaccharides (alginate, fucoidan, laminaran, and carrageenans, or their derived oligosaccharides) exhibit the same growth promotion activity (Hong et al., 2007; Khan et al., 2009; Craigie, 2011; González et al., 2013b; Rengasamy et al., 2015a, b). Other studies also indicate that the biostimulants effect is synergistically produced by all extract components: carbohydrates, proteins, minerals, vitamins, fatty acids, and phytohormones (Fornes et al., 2002; Zamani et al., 2013).

Recently in Mexico, the use of seaweed derivatives as biostimulants, biofertilizer, metabolic enhancer, and root promoters are included in crops as an alternative to the use of synthetic fertilizers, in order to reduce ecosystem degradation and contamination of agricultural land (Hernández-Herrera et al., 2014a). These reports show that a better understanding of their biological mode of action may enhance productivity in the future. The status and context for seaweed applications in Mexican agriculture are presented here.

\section{DIVERSITY OF SEAWEED FLORA WITH POTENTIAL AS BIOFERTILIZERS}

Mexico is the only Latin American country with temperate, subtropical, and tropical seas; thus, no other country in this region has such diversity in the marine environment (Robledo et al., 2013). The coastline of Mexico extends for $\sim 11,500 \mathrm{~km}$ (7,146 miles) and the exclusive economic zone covers approximately 3 million square kilometers. Five geographic regions in temperate to tropical latitudes with distinctive physiographic, geological, and climatic conditions favor the existence of a diverse algal flora. I) Baja California has an extensive latitudinal range and varied climatic patterns with the richest seaweed flora and large potential; 60 species cited as economically important are present (Aguilar-Rosas, 1982). II) The Gulf of California is considered an area of abundant seaweed with potential economic value; at least 55 species have commercial application (PachecoRuíz \& Zertuche-González, 1996) and there is high biomass which can be harvested sustainably. III) The Tropical Pacific is characterized by an impoverished phycoflora, with most species in the Rhodophyta and Phaeophyceae taxonomic groups (Pedroche \& Sentíes, 2003). Of the few studies addressing economic potential of seaweed none occur in the tropical region of Nayarit and Jalisco. Respectively, these areas have 16 and 4 species with potential for exploitation to produce seaweed liquid extracts for agriculture (Pacheco-Ruíz \& ZertucheGonzález, 1996; Hernández-Herrera et al., 2014a; Nicolás-Álvarez et al., 2014; Hernández-Herrera et al., 2016). However, algal biomass, populations, and ecological studies of seaweeds with economic interest are unknown for the region. IV) In the Gulf of Mexico, the flora has a continuous distribution (Garduño-Solórzano et al., 2005) represented by species of Ulva as having economic potential. V) The Mexican Caribbean has cold and warm water currents, influencing the distributional pattern of seaweeds, which is associated with the littoral and sub-littoral rocky areas; 28 species of seaweed with economic interest are recognized on the Yucatan coast (Robledo-Ramírez \& Freile-Pelegrín, 1998). The richest seaweed flora and potential for seaweed utilization in Mexico is shown in Figure 1.

\section{MANAGEMENT AND REGULATIONS IN MEXICO FOR THE EXPLOITATION AND HARVESTING OF SEAWEED}

In Mexico, the federal government manages all fisheries, including seaweed. However, under a law published in 2009, individual states can also manage sessile marine resources through an agreement with the federal government (Calvillo-Unna, 2009). Currently in Mexico, artisans carry out the harvest of this resource. For example, since 1966, Chondracanthus canaliculatus (Harvey) Guiry has been harvested by hand at low tide for carrageenan production. It is a sustainable harvest to date in San Quintin, Baja California. Aquaculture and harvesting of Kappaphycus alvarezii (Doty) Doty ex P.C.Silva in Dzilam de Bravo, Yucatan, is done by both men and women (Robledo et al., 2013; Rebours et al., 2014). At present, the harvest of this resource (such as in the case of Gelidium robustum (Gardner) Hollenberg et Abbott and Macrocystis pyrifera (Linnaeus) C. Agardh in Baja California), is carried out with small boats, where two fishermen using knives cut the upper portion of the alga; the maneuver typically requires 2 to 4 hours of labor (D0F, 2012).

\section{THE MEXICAN SEAWEED EXTRACT INDUSTRY}

In Mexico, the use of seaweed at an industrial level started in the first half of the last century. The agar industry began in 1941 with the AlgaMex company (Osario-Tafall, 1946) harvesting the 'red sargazo' Gelidium robustum by diving. Currently, G. robustum is the only algae processed in Mexico by the company Agarmex. The giant kelp Macrocystis pyrifera along with other algae of the genus Sargassum were initially exploited in Isla Todos Santos (Baja California), where potassium salts were obtained for agricultural purposes (Ortega, 1987), but the industry began in 1956 harvesting kelp as a source of alginates. One decade later, locals started harvesting Chondracanthus canaliculatus as a source of carrageenan, by hand during low tide. 


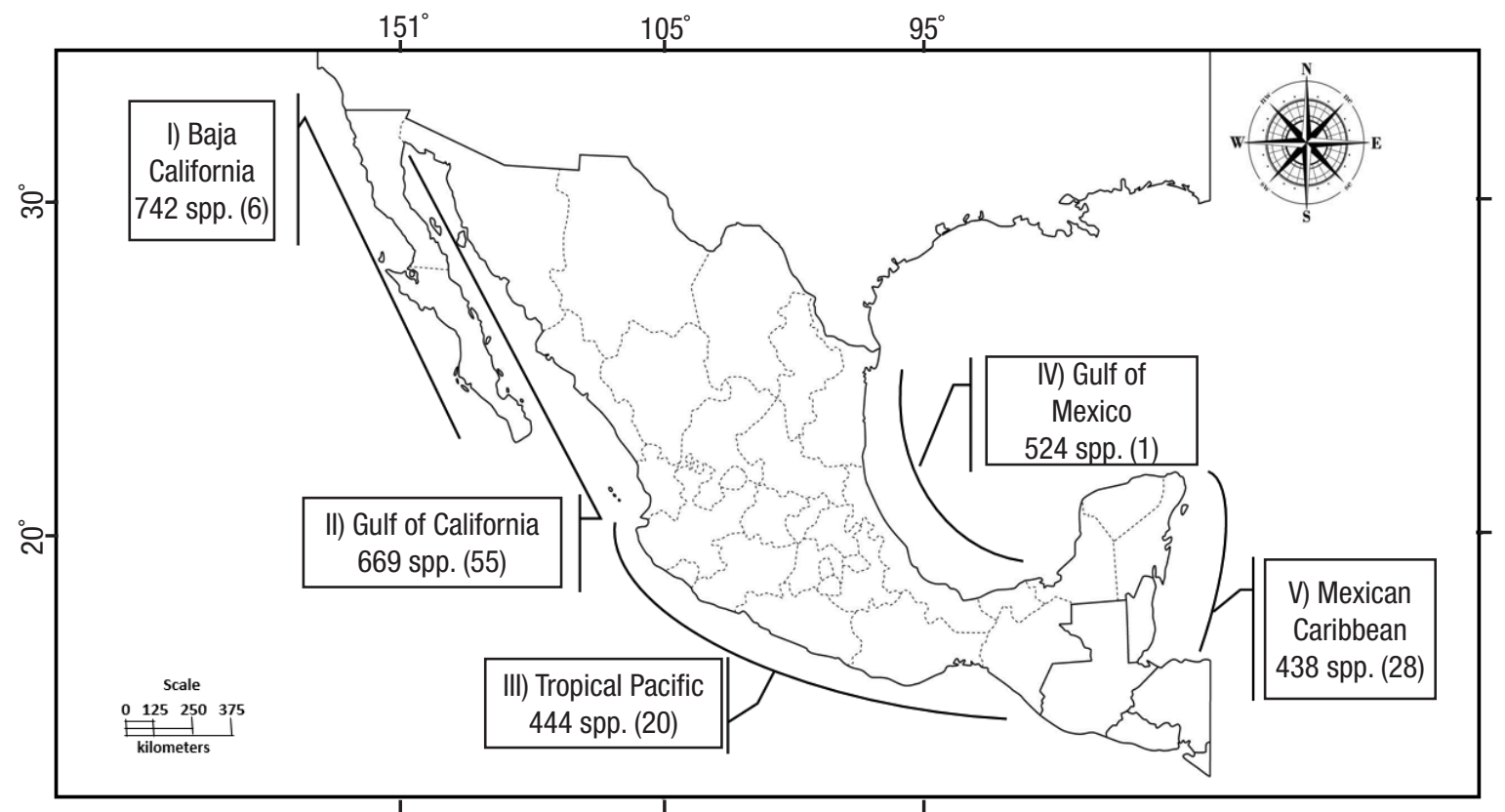

Figure 1. Seaweed flora in the five geographic regions of Mexico according to Pedroche and Sentíes (2003). The number of seaweeds with potential economic value appears in parenthesis.

For almost four decades, the Mexican industry remained in good shape; however, some important changes occurred in 2004, because the alginate industry shut down in the USA (CP Kelco), causing Mexico to stop exporting M. pyrifera. From 1956 to 2004, an annual average of 3,000 tons were harvested, using a boat designed specifically to harvest the available biomass, cutting the surface frond at one meter below the surface. The closing of this activity led to the search for other uses for $M$. pyrifera, such as the production of a supplement for balanced meals to feed red abalone [Haliotis rufescens (Swainson)]. The production of seaweed liquid extracts for application in agricultural crops also started. At present, Mexico's seaweed biomass, such as Gelidium robustum and Chondracanthus canaliculatus is sold to the phycocolloid industry for agar and carrageenan extraction (DOF, 2012; Zertuche-González et al., 2014). At present, G. robustum and M. pyrifera are used by the Algas Pacific company (http://algaspacific.com/) located in Ensenada in Baja California state, to produce seaweed liquid extracts, which are sold as a plant growth biostimulant. None of the four commercial seaweed species harvested in Mexico (M. pyrifera, G. robustum, C. canaliculatus, Gracilariopsis lemaneiformis (Bory de Saint-Vincent) E.Y. Dawson, Acleto y Foldvik) is endangered, thanks to the application of proper harvesting methods (Hernández-Garibay et al., 2006; Robledo \& Townsend, 2006; DOF, 2012).

Seaweed liquid fertilizer production is carried out by the private sector, which harvests and processes its raw materials. There are few companies working on liquid fertilizer production, employing 10 fishermen in algal harvesting and processing, from which about 20 more families benefit. The use of raw materials for food benefits about 20 families directly and indirectly, and it is increasing (DOF, 2012).

Algal biomass from six seaweed species are used to produce 14 commercial products (SAGARPA, 2012) such as biostimulants, biofer- tilizers, and root promoters (Table 1). According to our research, the production of commercial products in Mexico is based on algae biomass by conventional solvent extraction and hydrolysis with several methods under hydrothermal treatment with acid, neutral, and alkaline conditions.

\section{THE EFFECT OF SEAWEED AND ITS DERIVATES ON GERMINATION AND SEEDLING ESTABLISHMENT}

The seaweed liquid extracts for plant biostimulants produced in Mexico compete with similar products described by other authors. In published research (Table 2), trials were conducted in Mexico with 12 seaweed species to test biostimulant activity on crop growth.

The use of liquid seaweed extracts in Mexico began around the 1980s with the commercial product Algaenzims. Canales-López (1999) published a compilation of 12 years of research to find the precise doses of seaweed enzymes and the effects on plants and crop quality, as well as changes in the soil. The results showed a crop increase to 1-3 $t$ $\mathrm{ha}^{-1}$ by supplying from 1-3 $\mathrm{L} \mathrm{ha}^{-1}$ of the commercial product produced in the region. Another study by Villarreal-Sánchez et al. (2003) showed that Algaenzims contains a complex of viable (live) sea microorganisms, which includes nitrogen-fixing organisms, halophiles, molds and yeasts, and macro and microelements that highlight the importance of interactions between plants and the microorganisms contained in the product.

Additional research by García-Sahagún et al. (2014) assessed the effect of a commercial product (seaweed) on the development of gerbera (Gerbera jamesonii H. Bolus) under greenhouse conditions. Applying seaweed to gerbera had a positive effect on leaf number, stem number, stem length, and capitulum or flower head diameter (Fig. 2). 

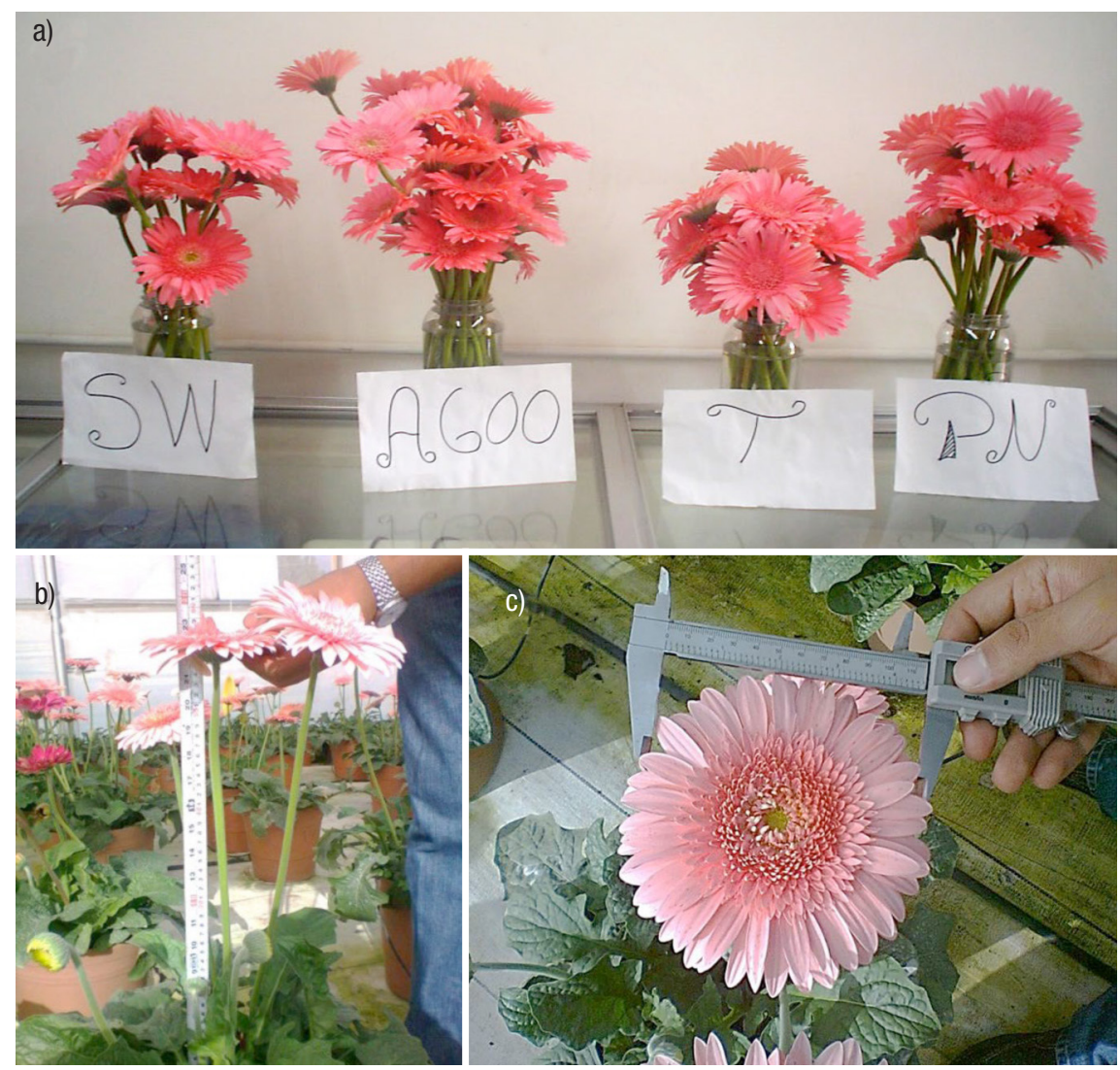

Figures 2a-c. a) Capitulum harvested according to treatment. From left to right, Seaweed (SW), Alga 600 (A600), Control (T), and Osmocalm (PN); b) Length of stems; c) Diameter of the capitulum. (Photos: María Luisa García Sahagún).

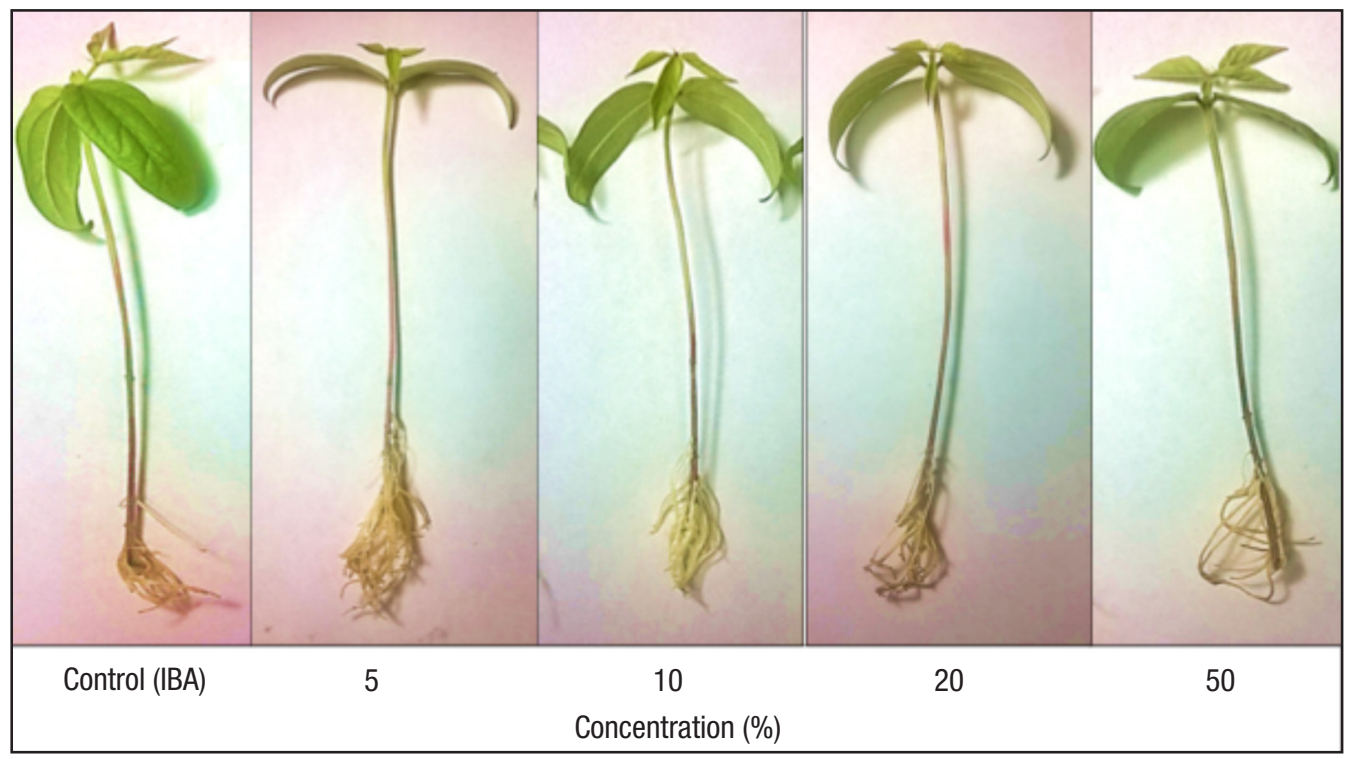

Figure 3. Activity of the extracts of Macrocystis pyrifera (Linnaeus) C. Agardh produced at different pH and temperature on the adventitious root formation from bean mung plants and IBA as reference (control). 
Table 1. Commercial seaweed products produced in Mexico.

\begin{tabular}{|c|c|c|c|c|c|}
\hline Product name & Seaweed species & Manufacturer & Application & $\mathrm{pH} / \mathrm{color}$ & Reference \\
\hline AgroKelp $®$ & $\begin{array}{l}\text { Macrocystis pyrifera (Linnaeus) } \\
\text { C. Agardh }\end{array}$ & $\begin{array}{l}\text { Algas y Bioderivados } \\
\text { Marinos, S.A de C.V }\end{array}$ & $\begin{array}{l}\text { Biostimulant } \\
\text { Biofertilizer }\end{array}$ & $\begin{array}{l}\text { 4.3-4.6 } \\
\text { Dark brown } \\
\text { liquid }\end{array}$ & $\begin{array}{l}\text { Khan et al. (2009), } \\
\text { Sharma et al. (2014) }\end{array}$ \\
\hline Algaenzims ${ }^{\mathrm{MR}}$ & $\begin{array}{l}\text { Sargassum spp., desert plants } \\
\text { and salts }\end{array}$ & Palau Bioquim, S.A. de C.V & Biofertilizer & Unspecified & $\begin{array}{l}\text { Sunapri et al. (2010), } \\
\text { Villarreal-Sánchez et } \\
\text { al. (2003) }\end{array}$ \\
\hline Algamar® & $\begin{array}{l}\text { Ascophyllum nodosum } \\
\text { (Linnaeus) Le Jolis, Sargassum } \\
\text { spp., Laminaria spp., } \\
\text { M. pyrifera, and Egregia } \\
\text { menziesii (Turner) Areschoug }\end{array}$ & Química Sagal, S.A. de C.V & Biostimulant & $\begin{array}{l}8.7-9.3 \\
\text { Black powder }\end{array}$ & In this study \\
\hline Algaroot ${ }^{\mathrm{MR}}$ & $\begin{array}{l}\text { Sargassum spp., desert plants } \\
\text { and salts }\end{array}$ & Palau Bioquim, S.A. de C.V & Root promoter & $\begin{array}{l}\text { Unspecified } \\
\text { liquid }\end{array}$ & In this study \\
\hline Cuajaenzims $^{\mathrm{MR}}$ & $\begin{array}{l}\text { Sargassum spp., desert plants } \\
\text { and salts }\end{array}$ & Palau Bioquim, S.A. de C.V & Biostimulant & Unspecified & In this study \\
\hline Frutoenzims ${ }^{\mathrm{MR}}$ & $\begin{array}{l}\text { Sargassum spp., desert plants } \\
\text { and salts }\end{array}$ & Palau Bioquim, S.A. de C.V & Biostimulant & Unspecified & In this study \\
\hline KelpromR & $\begin{array}{l}\text { M. pyrifera and } \\
\text { E. menziesii }\end{array}$ & $\begin{array}{l}\text { Tecniprocesos Biológicos, } \\
\text { S.A. de C.V }\end{array}$ & Biostimulant & 4.4 & $\begin{array}{l}\text { Khan et al. (2009), } \\
\text { Sharma et al. (2014) }\end{array}$ \\
\hline Kelprolizer® & $\begin{array}{l}\text { M. pyrifera, liquid fish protein } \\
\text { and humic acid }\end{array}$ & $\begin{array}{l}\text { Productos del Pacífico, S.A } \\
\text { de C.V }\end{array}$ & $\begin{array}{l}\text { Blend organic } \\
\text { fertilizer }\end{array}$ & $4.5-5.0$ & In this study \\
\hline Kelproot $\circledast$ & $\begin{array}{l}\text { M. pyrifera and Gelidium } \\
\text { robustum (Gardner) Hollenberg } \\
\text { et Abbott }\end{array}$ & $\begin{array}{l}\text { Algas y Extractos del } \\
\text { Pacífico Norte, S.A. de C.V }\end{array}$ & Root promoter & $\begin{array}{l}2.0 \text { to } 12.5 \\
\text { Dark brown liquid }\end{array}$ & In this study \\
\hline Kelprosoil $\circledast$ & M. pyrifera & $\begin{array}{l}\text { Productos del Pacífico, S.A } \\
\text { de C.V }\end{array}$ & Biostimulant & $\begin{array}{l}\text { Brown to greenish } \\
\text { liquid }\end{array}$ & $\begin{array}{l}\text { Khan et al. (2009), } \\
\text { Sharma et al. (2014) }\end{array}$ \\
\hline NPKelp® & $\begin{array}{l}\text { M. pyrifera and G. robustum } \\
\text { combined with Yucca } \\
\text { schidigera Roezl ex Ortgies and } \\
\text { humic acid }\end{array}$ & $\begin{array}{l}\text { Algas y Extractos del } \\
\text { Pacífico Norte, S.A. de C.V }\end{array}$ & Biofertilizer & $\begin{array}{l}4.5-5.1 \\
\text { Dark brown } \\
\text { liquid }\end{array}$ & In this study \\
\hline Seaweed® & M. pyrifera & Algas Marinas, S.A. de C.V & Biostimulant & $\begin{array}{l}4.0-4.5 \\
\text { brown }\end{array}$ & In this study \\
\hline Turboenzims $^{\mathrm{MR}}$ & $\begin{array}{l}\text { Sargassum spp., desert plants } \\
\text { and salts }\end{array}$ & Palau Bioquim, S.A. de C.V & $\begin{array}{l}\text { Metabolic } \\
\text { enhancers }\end{array}$ & Unspecified & In this study \\
\hline Vitalex ( & $\begin{array}{l}\text { Unspecified seaweed and } \\
\text { hydrolyzed fish }\end{array}$ & Química Sagal, S.A. de C.V & Biofertilizer & $\begin{array}{l}\text { 8.5-9.0 } \\
\text { Brown liquid }\end{array}$ & In this study \\
\hline
\end{tabular}

In recent published research by Briceño-Domínguez et al. (2014), a new method was developed to produce an alkaline seaweed liquid extract from M. pyrifera with high polysaccharide content. They suggested scaling up the process to industrial level. The most active extract was produced at pH 12 and $80{ }^{\circ} \mathrm{C}$. Under these conditions the seaweed li- quid extract enhanced adventitious root formation in a mung bean cutting assay, similar to the effect of indole-3-butyric acid (IBA) (Figure 3), and increased seedling growth in tomatos. Additionally, Nicolás-Álvarez et al. (2014) also found that a crude extract of Sargassum liebmannii J. Agardh is a potential germination promoter for Pachyrhizus erosus (L.) Urban. 


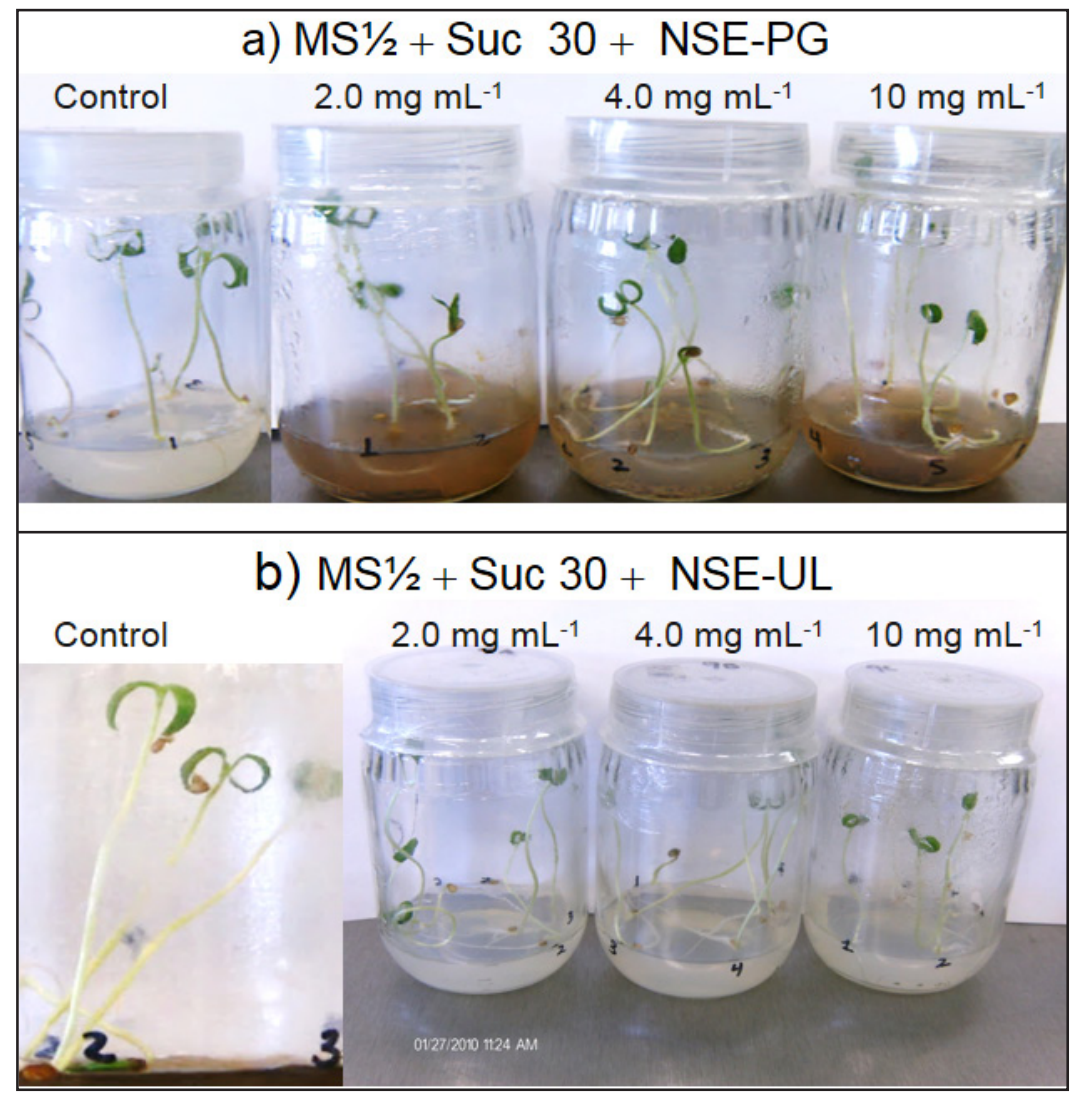

Figures 4a-b. Tomato (Solanum lycopersicum Linnaeus). Seedling growth under culture in vitro after two weeks of incubation exposed to different concentrations of seaweed extracts. a) Plants growing in control (half-strength MS with sucrose at $30 \mathrm{~g} \mathrm{~L}^{-1}$ ) and in different concentrations of neutral seaweed extracts from Padina gymnospora (Kützing) Sonder (NSE-PG); b) Neutral seaweed extracts of Ulva lactuca Linnaeus (NSE-UL) combined in half-strength MS with sucrose (30 $\mathrm{g} \mathrm{L}^{-1}$ ).

Hernández-Herrera et al. (2014a, 2016) found that neutral and alkaline seaweed extracts as well as polysaccharide-enriched extracts produced with tropical marine algae increased seed germination and tomato plant growth under different culture conditions (Fig. 4). In addition, enhanced adventitious root formation was observed in mung bean cuttings with polysaccharide-enriched extracts obtained with neutral rather than alkaline conditions (Fig. 5). Similarly, acid seaweed extracts increased biochemical parameters (Chlorophyll, total and reducer sugar) in the mung bean (Castellanos-Barriga et al., 2017), as well as seed germination of red radish (unpublished data) (Fig. 6).

The effect of green and brown seaweed extracts as elicitors to protect tomatos (Solanum lycopersicum Linnaeus) against the necrotrophic fungus Alternaria solani (Cooke) Wint. was published in Mexico. The algal extracts increased the defense activity of enzymes and proteinase inhibitors and expression of defense-related genes (HernándezHerrera et al., 2014b).

\section{CURRENT RESEARCH OF ALGAE EXTRACTS ON SOME CROPS}

The effects of both liquid and solid seaweed-derived biostimulants, biofertilizers, and root promoters was studied in Mexico by CICIMAR (Interdisciplinary Center of Marine Sciences of the National Polytech- nic Institute, CUCBA (University Center for Biological and Agricultural Sciences, acronym in Spanish) at the University of Guadalajara, and the Technical Superior Institute of Felipe Carrillo Puerto in Quintana Roo state, and included the following species: Macrocystis pyrifera, Ecklonia arborea (Areschoug) M.D. Rothman, Mattio \& J.J.Bolton (=Eisenia arborea), Sargassum liebmannii, S. horridum Setchell \& N.L. Gardner, S. natans (Linnaeus) Gaillon, S. fluitans (Børgesen) Børgesen, Padina gymnospora (Kützing) Sonder, Chnoospora minima (Hering) Papenfuss, Caulerpa sertularioides (S.G. Gmelin) M. Howe, Ulva lactuca Linnaeus, Acanthophora spicifera (M. Vahl) Børgesen, Gelidium robustum, and Gracilaria parvispora I.A. Abbott. These products were produced by acid, neutral, or alkaline extraction techniques.

The results obtained from this research could be useful to write a best-practice guide for regional agriculturists to improve harvesting quantity and quality in agriculture and horticulture. In conclusion, this review showed that seaweed extracts and polysaccharide-enriched extracts are increasingly used in Mexican crop production. Research in our laboratories demonstrated that crop species respond differently to the extracts (concentration and frequency of application); yet more crop-specific research is required to optimize seaweed extract application and to obtain the best possible outcome (i.e. return on investment). Most of the seaweed extract products currently in the market are extracts of whole seaweed. A number of questions require answers for 
Table 2. Seaweed used as biostimulant in crops.

\begin{tabular}{|c|c|c|c|c|c|}
\hline Geographic regions & Seaweed used to produce the extracts & $\begin{array}{l}\text { Type of } \\
\text { extracts }\end{array}$ & Crops & $\begin{array}{l}\text { Beneficial effects } \\
\text { under crops }\end{array}$ & References \\
\hline \multirow[t]{3}{*}{ I Baja California } & Macrocystis pyrifera (Linnaeus) C. Agardh & Alkaline & $\begin{array}{l}\text { Bean mung (Vigna } \\
\text { radiata) (L.) Wilczek } \\
\text { and tomato (Solanum } \\
\text { lycopersicum Linnaeus) }\end{array}$ & Growth promoter & Briceño-Domínguez et al. (2014) \\
\hline & Macrocystis pyrifera (Linnaeus) C. Agardh & Alcoholic & $\begin{array}{l}\text { Red radish (Raphanus } \\
\text { sativus Linnaeus) }\end{array}$ & Root promoter & Hernández-Alarcón (2014) \\
\hline & $\begin{array}{l}\text { Ecklonia arborea (=Eisenia arborea J. E. } \\
\text { Areschoug) }\end{array}$ & Alkaline & $\begin{array}{l}\text { Bean mung, lettuce } \\
\text { (Lactuca sativa } \\
\text { Linnaeus) and red } \\
\text { radish }\end{array}$ & Growth promoter & Martínez-Morales (2015) \\
\hline \multirow[t]{3}{*}{ II Gulf of California } & Acanthophora spicifera (M.Vahl) Børgesen & Alkaline & $\begin{array}{l}\text { Bean mung, lettuce } \\
\text { and red radish }\end{array}$ & Root promoter & Martínez-Morales (2015) \\
\hline & Ulva lactuca Linnaeus & Alkaline & $\begin{array}{l}\text { Bean mung, lettuce } \\
\text { and red radish }\end{array}$ & Root promoter & Martínez-Morales (2015) \\
\hline & Ulva lactuca & Acid & Bean mung & Root promoter & Castellanos-Barriga et al. (2017) \\
\hline \multirow[t]{7}{*}{ III Tropical Pacific } & $\begin{array}{l}\text { Caulerpa sertularioides } \\
\text { (S. G. Gmelin) M.Howe }\end{array}$ & Neutral & Tomato & $\begin{array}{l}\text { Enhance } \\
\text { germination }\end{array}$ & Hernández-Herrera et al. ( 2014) \\
\hline & Padina gymnospora (Kützing) Sonder & Neutral & Tomato & $\begin{array}{l}\text { Enhance } \\
\text { germination }\end{array}$ & Hernández-Herrera et al. ( 2014) \\
\hline & Sargassum liebmannii J. Agardh & Neutral & Tomato & $\begin{array}{l}\text { Enhance } \\
\text { germination }\end{array}$ & Hernández-Herrera et al. ( 2014) \\
\hline & Ulva lactuca & Neutral & Tomato & $\begin{array}{l}\text { Enhance } \\
\text { germination }\end{array}$ & Hernández-Herrera et al. ( 2014) \\
\hline & Padina gymnospora & $\begin{array}{l}\text { Neutral } \\
\text { and alkaline }\end{array}$ & Bean mung and tomato & Root promoter & Hernández-Herrera et al. ( 2016) \\
\hline & Ulva lactuca & $\begin{array}{l}\text { Neutral } \\
\text { and alkaline }\end{array}$ & Bean mung and tomato & Root promoter & Hernández-Herrera et al. ( 2016) \\
\hline & Sargassum liebmannii & Neutral & $\begin{array}{l}\text { Jicama (Pachyrhizus } \\
\text { erosus Linnaeus) }\end{array}$ & $\begin{array}{l}\text { Germination } \\
\text { promoter }\end{array}$ & Nicolás-Álvarez et al. (2015) \\
\hline IV Gulf of Mexico & Ulva lactuca & Unspecific & Unspecific & Growth promoter & Garduño-Solórzano et al., 2005 \\
\hline \multirow[t]{5}{*}{ V Mexican Caribbean } & Hydroclathrus clathratus (C. Agardh) M. Howe & Unspecific & Unspecific & Growth promoter & $\begin{array}{l}\text { Robledo-Ramírez y } \\
\text { Freile-Pelegrín (1998) }\end{array}$ \\
\hline & Sargassum filipendula C. Agardh & Unspecific & Unspecific & Growth promoter & $\begin{array}{l}\text { Robledo-Ramírez y } \\
\text { Freile-Pelegrín (1998) }\end{array}$ \\
\hline & Sargassum fluitans (Børgesen) Børgesen & Unspecific & Unspecific & Growth promoter & $\begin{array}{l}\text { Robledo-Ramírez y } \\
\text { Freile-Pelegrín (1998) }\end{array}$ \\
\hline & Turbinaria tricostata E.S. Barton & Unspecific & Unspecific & Growth promoter & $\begin{array}{l}\text { Robledo-Ramírez y } \\
\text { Freile-Pelegrín (1998) }\end{array}$ \\
\hline & Turbinaria turbinata (Linnaeus) Kuntze & Unspecific & Unspecific & Growth promoter & $\begin{array}{l}\text { Robledo-Ramírez y } \\
\text { Freile-Pelegrín (1998) }\end{array}$ \\
\hline
\end{tabular}

better use of seaweed resources and their extracts in crops. 1) Does the same raw material processed by different extraction methods lead to extracts with different characteristics? (Briceño-Domínguez et al., 2014; Hernández-Herrera et al., 2016). 2) How long does the effect persist after application of seaweed extracts? (Hernández-Herrera et al., 2014b). 3) Is it possible to combine different extracts from diffe- rent seaweeds at different concentrations for synergistic effects? (Hernández-Carmona \& Di Filippo-Herrera, unpublished). It would also be interesting to study the physiological effects of specific chemical components in order to develop a second generation of seaweed products with specific plant biostimulants activity. 

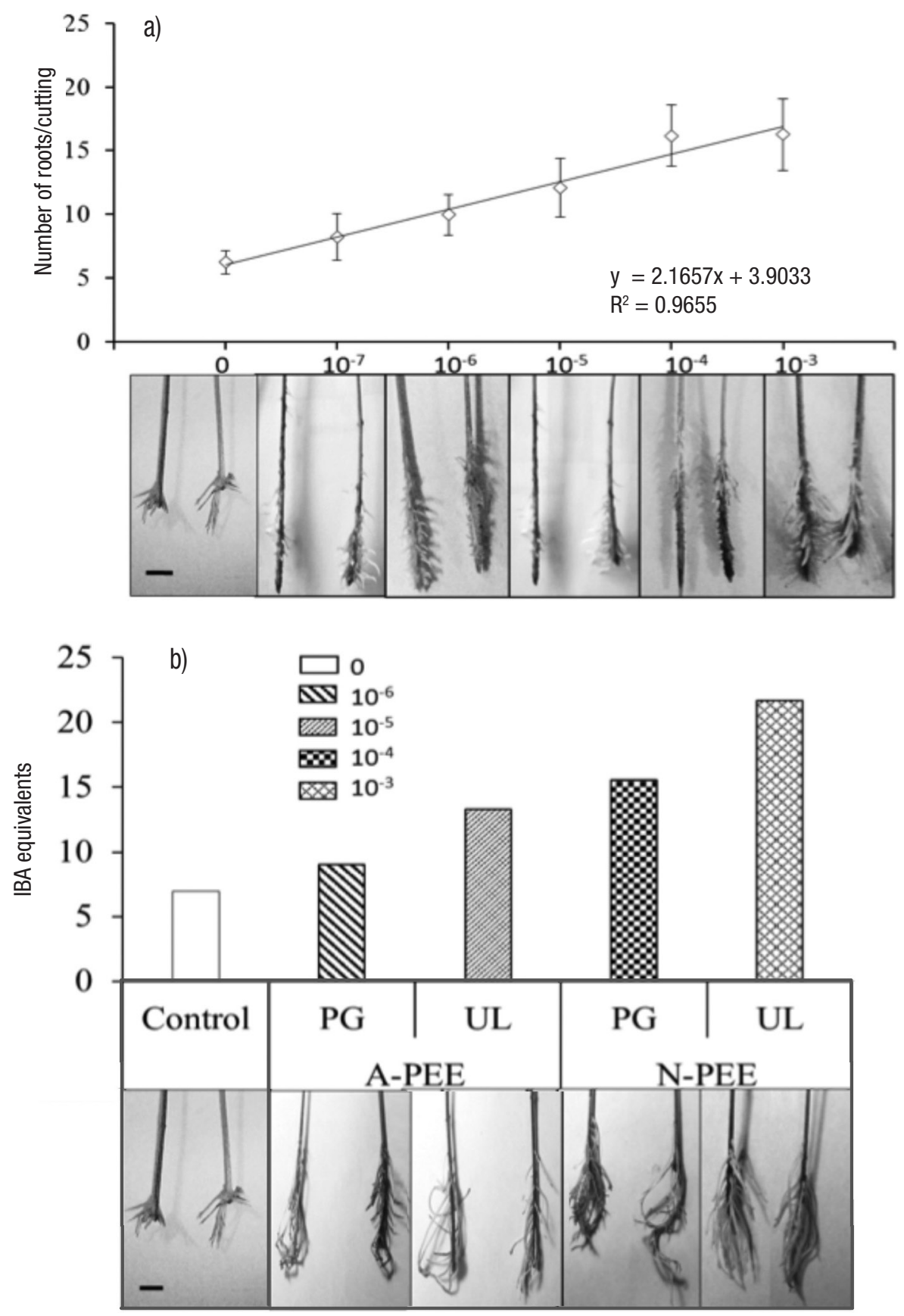

Figures 5a-b. Root inducer activity. a) A standard curve for root formation in mung bean plants treated with indol-3-butyric acid (IBA) at $10^{-7}, 10^{-6}, 10^{-5}, 10^{-4}$, and $10^{-3}$ concentration (M) as reference; b) IBA equivalents (M) on root formation with polysaccharide-enriched extracts obtained with neutral (N-PEE) and alkaline (A$\mathrm{PEE}$ ) conditions from Ulva lactuca Linnaeus (UL) and Padina gymnospora (Kützing) Sonder (PG) at concentration of $1.0 \mathrm{mg} \mathrm{mL}^{-1}$. Values represent the mean of $\mathrm{n}=20$ seedlings, bars represent standard errors. Bar $=1 \mathrm{~cm}$.

\section{ACKNOWLEDGMENTS}

The authors wish to thank Dra. Laurie Anne McConnico for her Englishlanguage editing assistance. G. Hernández thanks the Instituto Politécnico Nacional for financially supporting his research. He also gratefully acknowledges support from the "Beca de Exclusividad (COFAA)" and "Estímulo al Desempeño de los Investigadores (EDI)". The authors thank the journal reviewers for their valuable comments, suggestions, and guidance. 

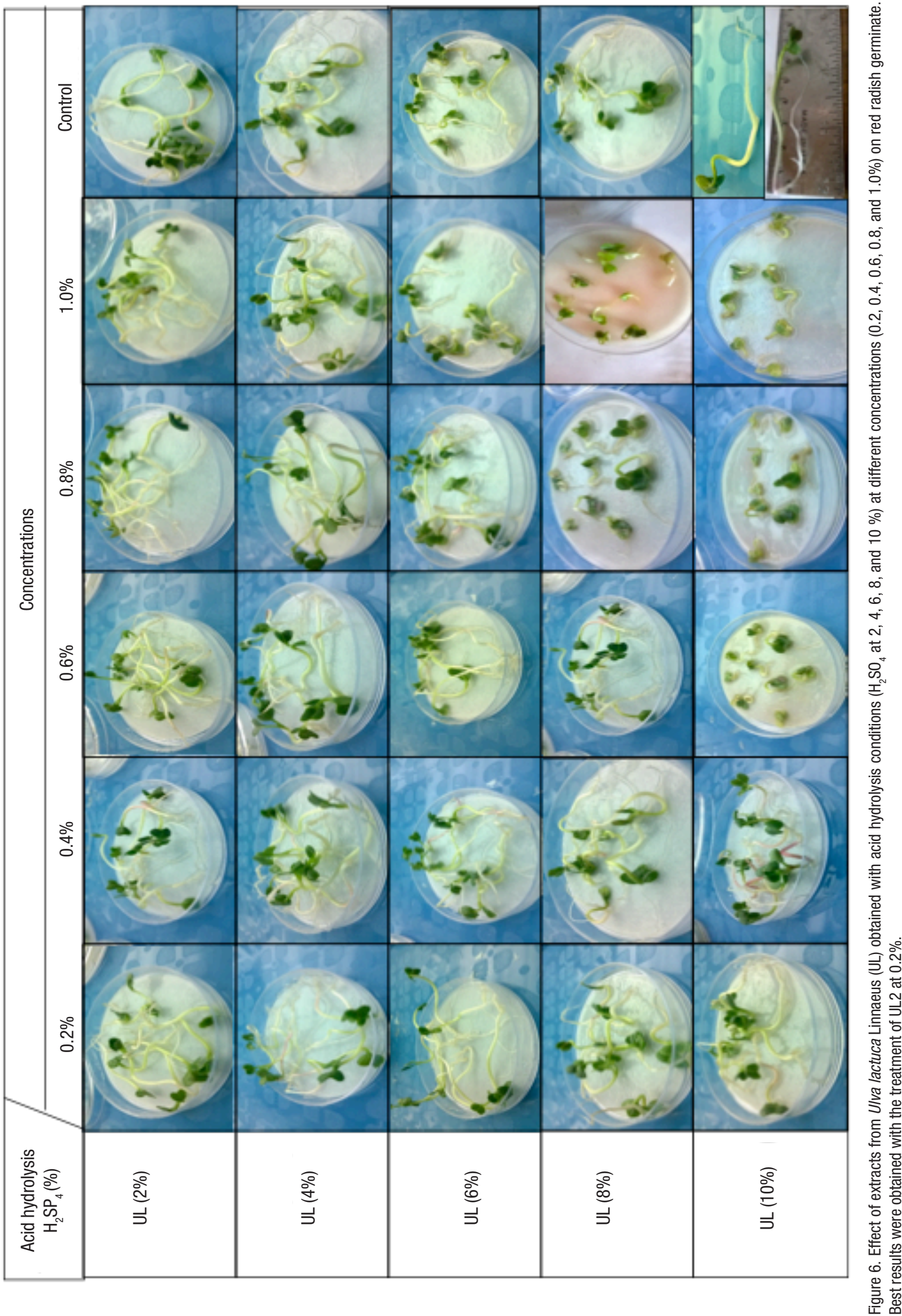


\section{REFERENCES}

Agullar-Rosas, L. E. 1982. Ocurrencia de algas cafés (Phaeophyta) en la bahía Todos Santos, Baja California. Ciencias Marinas 8: 25-34. Available online at: http://www.cienciasmarinas.com.mx/index. php/cmarinas/issue/view/38/showToc

Ali, N., A. Farrell., A. Ramsubhag \& J. Jayaraman. 2016. The effect of Ascophyllum nodosum extract on the growth, yield and fruit quality of tomato grown under tropical conditions. Journal of Applied Phycology 28: 1353-1362. DOI:10.1007/s10811-015-0608-3

Calvillo-Unna L. A 2009. Un caso de simulación del federalismo. La ley general de pesca y acuacultura sustentables. Alegatos - Revista Jurídica de la Universidad Autónoma Metropolitana 71: 127138. https://www.azc.uam.mx/publicaciones/alegatos/pdfs/64/7108.pdf

Castellanos-Barriga, L. G., F. Santacruz-Ruvalcaba., G. Hernández-Carmona., E. Ramirez-Briones \& R. M. Hernández-Herrera. 2017. Effect of seaweed liquid extracts from Ulva lactuca on seedling growth of mung bean (Vigna radiata). Journal of Applied Phycology 29: 2479-2488. D0I:10.1007/s10811-017-1082-x

Briceño-Dominguez, D., G. Hernández-Carmona., M. Moyo., W. Stirk \& J. Van StADEN. 2014. Plant growth promoting activity of seaweed liquid extracts produced from Macrocystis pyrifera under different $\mathrm{pH}$ and temperature conditions. Journal of Applied Phycology 26: 22032210. DOI:10.1007/s10811-014-0237-2

Canales-López, B. 1999. Enzimas-algas: posibilidades de su uso para estimular la producción agrícola y mejorar los suelos. Terra 17 (3): 271-276. Available online at: https://chapingo.mx/terra/contenido/17/3/art271-276.pdf

Craigie, J. S. 2011. Seaweed extract stimuli in plant science and agriculture. Journal of Applied Phycology 23: 321-335. D0I:10.1007/ s10811-010-9560-4

dOF Diario Oficial de la Federación. 2012. Plan de Manejo para la Pesquería de Macroalgas en Baja California, México. Secretaría de Agricultura, Ganadería, Desarrollo Rural, Pesca y Alimentación. (SAGARPA). Available online at: http://dof.gob.mx/nota_detalle_popup. php?codigo=5280840. (downloaded 14 June 2016).

Fornes, F., M Sánchez-Perales \& J.L. Guadiola. 2002. Effect of a seaweed extract on the productivity of 'de Nules' Clementine mandarin and navelina orange. Botanica Marina 45: 486-489

Garcia-Sahagún, M. L., A. De Luna Vega., C. Zuñiga-Campa., 0. A. BañuelosGutiérRez \& M. Silva-Echeverría. 2014. Efecto de algas marinas en el desarrollo de Gerberajamesonii (Asteraceae). e-Cucba 2: 39-45. Available online at: http://e-cucba.cucba.udg.mx/index.php/e-Cucba/article/view/14/pdf_7

Garduño-Solórzano, G., J. L. Godínez-Ortega \& M. M. Ortega. 2005. Distribución geográfica y afinidad por el sustrato de las algas verdes (Chlorophyceae) bénticas de las costas mexicanas del Golfo de México y Mar Caribe. Boletín de la Sociedad Botánica de México 76: 61-78. Available online at: http://www.redalyc.org/pdf/577/57707606.pdf

Gireesh, R., C. K. Haridevi \& J. Salikutty. 2011. Effect of Ulva lactuca extract on growth and proximate composition of Vigna unguiculata $\mathrm{L}$.
Walp. Journal of Research in Biology 8: 624-630. Available online at: http://jresearchbiology.com/ Documents/RA0148.pdf.

González, A., J. Castro, J. Vera \& A. Moenne. 2013a. Seaweed oligosaccharides stimulate plant growth by enhancing carbon and nitrogen assimilation, basal metabolism, and cell division. Journal of Plant Growth Regulation 32: 443-448. D0I:10.1007/s00344-012-93091

GonzÁlez, A., R. A. Contreras \& A. Moenne. 2013b. Oligo-carrageenans enhance growth and contents of cellulose, essential oils and polyphenolic compounds in Eucalyptus globulus trees. Molecules 18: 8740-8751. D0I:10.3390/molecules18088740.

Gupta, S. \& N. Abu-Ghannam. 2011. Recent developments in the application of seaweeds or seaweed extracts as a means for enhancing the safety and quality attributes of foods. Innovative Food Science \& Emerging Technologies 12: 600-609. D0I:10.1016/j. ifset.2011.07.004

Hernández-Alarcón, I. 2014. Evaluación de un extracto alcalino del alga Macrocystis pyrifera (L.) C. Agardh, sobre el crecimiento de vegetales terrestres. Tesis de Licenciatura en Biología Marina. Universidad Autónoma de Baja California Sur. México. 47 p.

Hernández-Garibay, E., J. Guardado-Puentes., J. Bautista-Alcantar \& R. ReyesTISNADO. 2006. Macroalgas del Oceáno Pacífico. In: Cuellar J. (Ed). Sustentabilidad y Pesca Responsable en México. Instituto Nacional de la Pesca, SAGARPA. pp. 235-244.

Hernández-Herrera, R. M., F. Santacruz-Ruvalcaba., M. A. Ruiz-López., J. NorRie \& G. Hernández-Carmona. 2014a. Effect of liquid seaweed extracts on growth of tomato seedlings (Solanum lycopersicum L.). Journal of Applied Phycology 26: 619-628. D0I:10.1007/s10811013-0078-4

Hernández-Herrera, R. M., G. Virgen-Calleros., M. A. Ruiz-López., J. ZañudoHernández., J. P. Délano-Frier \& C. SÁnchez-Hernández. 2014b. Extracts from green and brown seaweeds protect tomato (Solanum lycopersicum) against the necrotrophic fungus Alternaria solani. Journal of Applied Phycology 26: 1607-1614. D0I:10.1007/s10811-0130193-2

Hernández-Herrera, R. M., F. Santacruz-Ruvalcaba, J. Zañudo-Hernández \& G. Hernández-Carmona. 2016. Activity of seaweed extracts and polysaccharide-enriched extracts from Ulva lactuca and Padina gymnospora as growth promoters of tomato and mung bean plants. Journal of Applied Phycology 28: 2549-2560. D0I:10.1007/s10811-0150781-4

Hong, D. D., H. M. Hien \& P. N. Son. 2007. Seaweeds from Vietnam used for functional food, medicine and biofertilizer. Journal of Applied Phycology 19: 817-826. D0I:10.1007/s10811-007-9228-x

Jayaraj, J., A. Wan., M. Rahman \& Z. K. Punja. 2008. Seaweed extract reduces foliar fungal diseases on carrot. Crop Protection 10: 13601366. D0l:10.1016/j.cropro.2008.05.005

Jayaraman, J \& N. Alı. 2015. Use of seaweed extracts for disease management of vegetable crops. In: Ganesan S., Vadivel K., Jayaraman J. (Eds.). Sustainable Crop Disease Management using Natural Products. Oxfordshire, UK, CABI, pp. 160-183. DOI:10.1079/9781780643236.0160 
Khan, W., U. P. Rayirath., S. Subramanian., M. N. Jithesh., P. Rayorath., D. M. Hodges., A. T. Critchley., D. Laporte., J. Vera., N. P. Chandía., E. A. Zúñiga., B. Matsuhiro \& A. Moenne. 2007. Structurally unrelated algal oligosaccharides differentially stimulate growth and defense against tobacco mosaic virus in tobacco plants. Journal of Applied Phycology 19: 79-88. D0l:10.1007/s10811-006-9114-y

Martínez-Morales, J. S. 2015. Evaluación de extractos de algas marinas como promotores de crecimiento en cultivos terrestres. Tesis de Maestría, CICIMAR-IPN, México. 50 p.

Mattner, S. W., D. Wite., D. A. Riches., I. J. Porter \& T. Ariol. 2013. The effect of kelp extract on seedling establishment of broccoli on contrasting soil types in southern Victoria, Australia. Biological Agriculture \& Horticulture 29: 258-270. D0I:10.1080/01448765.2013.83 0276

Nicolás-Álvarez, D. E., L. E. Mateo-Cid., A.C. Mendoza-González., M. Gutiérrez-Ladrón De Guevara \& A. Reyes-Chaparro. 2014. Utilization of Seaweed Sargassum liebmannii extract as a stimulant of germination of Pachyrhizus erosus. Journal of Chemical, Biological and Physical Sciences (JCBSC) 4: 56-61.

ORTEGA, M. M. 1987. Doce años de ficología en México (971-1983). In: Gómez Aguirre. S. y V. Arenas Fuentes (Eds.). Contribuciones en hidrobiología. Memoria de la Reunión Alejandro Villalobos (24 al 26 de octubre de 1983). Universidad Nacional Autónoma de México. México, D.F. pp. 155-186.

Osorio-Tafall, B. F. 1946. Anotaciones sobre algunos aspectos de la hidrobiología Mexicana. Revista de la Sociedad Mexicana de Historia Natural 7:139-165. Available online at: http://repositorio.fciencias. unam.mx:8080/jspui/bitstream/11154/142549/1/7VAnotacionesS obre.pdf

Pacheco-Ruiz, I. \& J. A. Zertuche-González. 1996. The commercially valuable seaweeds of the Gulf of California. Botánica Marina 39: 201206. DOI:10.1515/botm.1996.39.1-6.201

Pedroche, F. F \& A. Senties. 2003. Mexican marine phycology. Diversity and problems. Hidrobiológica 13: 23-32. Available online at: http:// www.scielo.org.mx/pdf/hbio/v13n1/v13n1a3.pdf

Rayorath, P., M. N. Jithesh., A. Farid., W. Khan., R. Palanisamy., S. D. Hankins., A. T. Critchley \& B. Prithiviraj. 2008. Rapid bioassays to evaluate the plant growth promoting activity of Ascophyllum nodosum (L.) Le Jol. using a model plant, Arabidopsis thaliana (L.) Heynh. Journal of Applied Phycology 20: 423-429. D0I:10.1007/s10811-007-92806

Rebours, C., E. Marinho-Soriano, J. A. Zertuche-González, L. Hayashi, J. A. Vásquez, P. Kradolfer, G. Soriano, R. Ugarte, M. H. Abreu, I. Bay-Larsen, G. Hovelsrud, R. Rødven \& D. Robledo. 2014. Seaweeds: an opportunity for wealth and sustainable livelihoods for coastal communities. Journal of Applied Phycology 26: 1939-1951. D0I:10.1007/s10811014-0304-8

Rengasamy, K. R. R., M. G. Kulkarni, W. A. StiRk \& J. Van Staden. 2015a Eckol a new plant growth stimulant from the brown seaweed Ecklonia maxima. Journal of Applied Phycology 27: 581-587. D0I:10.1007/ s10811-014-0337-z
Rengasamy, K. R. R., M. G. Kulkarni., W. A. StiRk \& J. Van Staden. $2015 \mathrm{~b}$. Eckol improves growth, enzyme activities, and secondary metabolite content in maize (Zea mays cv. Border King). Journal of Plant Growth Regulation 34: 410-416. D0I:10.1007/s00344-015-9479-8

Robledo, D., E. Gasca-Leyva \& J. Fraga. 2013. Social and economic dimensions of carrageenan seaweed farming in Mexico. In: Valderrama D., Cai J., Hishamunda N., Ridler N. (Eds.). Social and Economic Dimensions of Carrageenan Seaweed Farming. Fisheries and Aquaculture Technical Paper No. 580. Rome, FAO, pp. 185-204.

Robledo, D. \& W. TownSEND. 2006. Seaweed and mangroves: improving environmental practices in coastal communities to secure sustainable livelihoods. In: Breton Y., D. Brown, E.B. Davey, M. Haughton M \& L. Ovares (Eds). Coastal Resource Management in the Wider Caribbean: Resilience, Adaptation, and Community Diversity. Kingston, Jamaica, Ian Randle Publishers; Ottawa, International DeveIopment Research Centre 190 p. Available online at: https://www. researchgate.net/publication/256183984_SEAWEEDS_AND_MANGROVES_IMPROVING_ENVIRONMENTAL_PRACTICES_IN_COASTAL_COMMUNITIES_OF_MEXICO_AND_JAMAICA

Robledo-Ramírez, D. \& Y. Freile-Pelegrín. 1998. Macroflora marina de interés económico de las costas de Yucatán. In: Benítez H., E. Vega, A. Peña \& S. Ávila. (Eds.). Aspectos Económicos Sobre la Biodiversidad de México. México, CONABI0-SEMARNAP, pp. 167-179.

RothäUsleR, E., L. Gutow \& M. Thiel. 2012. Floating seaweeds and their communities. In: C. Wiencke \& K. Bischof (Eds.). Seaweed Biology Novel Insights into Ecophysiology, Ecology and Utilization, Ecological Studies 219, Berlin Heidelberg, Springer, 21 p. D0I:10.1007/978-3642-28451-9_17

Sagarpa (Secretaría de Agricultura, Ganadería, Desarrollo Rural, Pesca y AllMENTACIÓN). 2012. Reglas de Operación de los Programas de SAGARPA. DOF del 30 November 2012. Available online at: http://inapesca.gob.mx/portal/documentos/publicaciones/30112012\%20 SAGARPA.pdf (Downloaded 10 May 2016).

Satish, L., S. A. Ceasar, J. Shilpha, S. A. Rency, P. Rathinapriya \& M. Ramesh. 2015a. Direct plant regeneration from in vitro-derived shoot apical meristems of finger millet (Eleusine coracana (L.) Gaertn.). In Vitro Cellular \& Devolpmental Biology-Plant 51: 192-200. D0I:10.1007/ s11627-015-9672-2

Satish, L., R. Rameshrumar, P. Rathinapriya, S. Pandian, A. S. Rency, T. Sunitha \& M. Ramesh. 2015b. Effect of seaweed liquid extracts and plant growth regulators on in vitro mass propagation of brinjal (Solanum melongena L.) through hypocotyl and leaf disc explants. Journal of Applied Phycology 27: 993-1002. D0I:10.1007/s10811-0140375-6

Sharma, H. S., C. Fleming, C. Selby, J. R. Rao \& T. Martin. 2014. Plant biostimulants: a review on the processing of macroalgae and use of extracts for crop management to reduce abiotic and biotic stresses. Journal of Applied Phycology 26: 465-490. D0I:10.1007/s10811013-0101-9

Sunarpl, A., R. Jupri, N. I. Kurnianingsih \& A. Nikmatullah. 2010. Effect of seaweed extracts on growth and yield of rice plants. Bioscience 2 (2): 73-77.DOl:10.13057/nusbiosci/n020204 
Thirumaran, G., M. Arumugam, R. Arumugam \& P. Anantharaman. 2009. Effect of seaweed liquid fertilizer on growth and pigment concentration of Abelmoschus esculentus (I) Medikus. American-Eurasian Journal of Agronomy 2 (2): 57-66. Available online at: https://www.idosi. org/aeja/2(2)09/3.pdf

TuRAn, M \& C. KöSE. 2004. Seaweed extracts improve copper uptake of grapevine. Acta Agriculturae Scandinavica, Section B - Soil \& Plant Science 54: 213-220. D0I:10.1080/09064710410030311

Vera, J., J. Castro, A. González, H. Barrientos, B. Matsuhiro, P. Arce, G. ZÚNIIGA \& A. MoenNe. 2011a. Long term protection against tobacco mosaic virus induced by the marine alga oligo-sulphatedgalactan Poly-Ga in tobacco plants. Molecular Plant Pathology 12: 437-447. DOI:10.1111/j.1364-3703.2010.00685.x

Vera, J., J. Castro, A. González \& A. Moenne. 2011b. Seaweed polysaccharides and derived oligosaccharides stimulate defense responses and protection against pathogens in plants. Marine Drugs 9: 25142525. DOI:10.13057/nusbiosci/n020204

Villarreal-Sánchez, J. A., A. Llyina, L. P. Mendez-Jiménez, V. Robledo-Torres, R. Rodríguez-Herrera, B. Canales-López \& J. Rodríguez-Martínez. 2003. Isolation of microbial groups from a seaweed extract and comparison of their effects on a growth of pepper culture (Capsicum annuum L.). Moscow University Chemistry Bulletin 44: 92-96. Available online at: http://www.chem.msu.su/rus/vmgu/031/92.pdf
Vinoth, S., P. Gurusaravanan \& N. Jayabalan. 2012a. Effect of seaweed extracts and plant growth regulators on high-frequency in vitro mass propagation of Lycopersicon esculentum $\mathrm{L}$ (tomato) through double cotyledonary nodal explant. Journal of Applied Phycology 24:13291337. D0I:10.1007/s10811-011-9717-9

Vinoth, S., P. Gurusaravanan \& N. Jayabalan. 2012b. Erratum to: effect of seaweed extracts and plant growth regulators on high-frequency in vitro mass propagation of Lycopersicon esculentum $L$ (tomato) through double cotyledonary nodal explant. Journal of Applied Phycology 24: 1339-1340. DOI:10.1007/s10811-011-9748-2

Vinoth, S., P. Gurusaravanan \& N. Jayabalan. 2014. Optimization of somatic embryogenesis protocol in Lycopersicon esculentum $\mathrm{L}$. using plant growth regulators and seaweed extracts. Journal of Applied Phycology 26: 1527-1537. D0l:10.1007/s10811-013-0151-z

Zertuche-González, J. A., M. Sánchez-Barredo, J. M. Guzmán-Calderón \& Z. Altamirano-Gómez. 2014. Eisenia arborea J.E. Areschoug as abalone diet on an IMTA farm in Baja California, México. Journal of Applied Phycology 26 (2): 957-960. D0I:10.1007/s10811-013-0138-9

Zamani, A., S. Khorasaninejad \& B. Kashefl. 2013. The importance role of seaweeds of some characters of plant. International Journal of Agriculture and Crop Sciences 5 (16): 1789-1793.

Zhang, X \& R. E. Schmidt. 2000. Hormone-containing products' impact on antioxidant status of tall fescue and creeping bent grass subjected to drought. Crop Science 40: 1344-1349. D0I:10.2135/ cropsci2000.4051344x 